POLSKA AKADEMIA UMIEJĘTNOŚCI

PRACE KOMISJI KULTURY SŁOWIAN PAU

TOM XI

Rafat MajereK

Uniwersytet Jagielloński, Kraków

\title{
REPETYCJE I PRZEWARTOŚCIOWANIA. ZAGADNIENIE TRADYCJI NARODOWEJ W DYSKURSIE SŁOWACKIM PO 1989 R.
}

Problematyka tożsamości narodowej, a więc przede wszystkim kwestie dotyczące kształtu pamięci zbiorowej, stosunku do narodowej tradycji i wszystkich elementów ją konstytuujących, w okresie zmiany systemowej w krajach słowiańskich stała się kluczowym tematem rozważań w dyskursie kulturowym. Propozycje wskazujące kierunek, jaki procesy autoidentyfikacyjne powinny obrać, sposób prowadzenia dyskusji tym zagadnieniom poświęconych oraz konsekwencje wyboru określonych strategii budowania nowego poczucia wspólnoty u poszczególnych narodów słowiańskich, przyjmowały różne formy, wynikające zarówno z uwarunkowań historycznych, jak i aktualnych problemów. Maria Bobrownicka we wstępie do książki Patologie tożsamości narodowej w postkomunistycznych krajach słowiańskich, komentując te procesy, wskazuje jednocześnie konieczność ich krytycznego opisu:

Społeczeństwa słowiańskie wyzwolone z komunizmu ciągle jeszcze nie mogą się odnaleźć w nowej rzeczywistości liberalno-demokratycznego świata prawa, w jakim się znalazły bardziej lub mniej niespodziewanie. Nieprzystosowanie kulturowe, oczywiście bardzo różne w poszczególnych krajach postkomunistycznej strefy Europy co do stopnia swego nasilenia, przejawia się $\mathrm{w}$ wielu dziedzinach, między innymi, a może przede wszystkim w tym, co dotyczy pojmowania tożsamości, zwłaszcza narodowej. Tożsamość stała się nieomal dyżurnym tematem i transparentnym hasłem naszych czasów, lecz na rozległym polu semantycznym tej kategorii ujawniły się syndromy poważnych schorzeń. [...] Płaszczyzny nieprzystosowania kulturowego, rodzące ewidentne stany patologiczne, wymagają zarówno systematyzacji typologiczno-opisowej, jak i prób wyjaśnienia historycznego, socjologicznego, kulturoznawczego itd. Podobnie domagają się takiej wieloaspektowej interpretacji dzisiejsze strategie adaptacyjne społeczeństw tego obszaru do życia w świecie postkomunistycznym, który od ludzi ubezwłasnowolnionych przez po- 
przedni system żąda teraz indywidualnej odpowiedzialności, co wydaje się w pewnych okolicznościach zbyt trudne ${ }^{1}$.

Z perspektywy ćwierćwiecza mijającego od wydarzeń 1989 r. zagadnienia wyróżnione przez polską badaczkę, w ramach ujęcia modelowego, którego niedoskonałości, oczywiście, należy brać pod uwagę, w przypadku Słowacji przedstawione być mogą jako przestrzeń rywalizacji określonych propozycji organizowania pamięci kulturowej, która, jako stała moc normatywna i formatywna ${ }^{2}$, buduje poczucie wspólnotowości, wyznacza sfery wartości najważniejszych, określa charakter relacji z innymi narodami oraz sposoby rozumienia własnego miejsca $w$ strukturach ponadnarodowych. Zerwanie z komunizmem, a tym samym zanegowanie oficjalnej kultury ideologicznego monologu, stworzyło warunki do autorefleksji i podjęcia dyskusji, w wyniku których stopniowo doszło do krystalizacji stanowisk dotyczących pożądanego kształtu narodowej tożsamości, wynikającego przede wszystkim z interpretacji słowackiej przeszłości i form rozumienia rodzimej tradycji.

Wyeksponowane w tytule artykułu pojęcia repetycji i przewartościowań, dzięki którym postaram się uporządkować problematykę, wskazują, najogólniej mówiąc, na dwa podstawowe kierunki refleksji nad kształtem kultury i tradycji narodowej, kanonu literatury itd., jakie wyróżnić można w dyskursie słowackim po 1989 r. Pierwszy z nich związany jest z dążeniem do powtórzenia, często bezkrytycznego i bezrefleksyjnego, a przy tym wyraźnie funkcjonalnego wobec aktualnej polityki, pewnych zakorzenionych, traktowanych w kategoriach „naturalności” i „oczywistości” konstrukcji. Kierunek drugi oparty jest na przekonaniu o konieczności poddania krytycznej refleksji pewnych elementów świadomości narodowej i kulturowej, zmierza do ich rewizji i destabilizacji, wykazania ich konstruktywistycznego, związanego z określonymi celami charakteru. Podobnie zagadnienie to rozważa Rudolf Chmel, który, powołując się na ustalenia Romana Holca, stwierdza, że w ramach słowackiej „debaty narodowej" realizowane są dwie interpretacje słowackiej historii, nazwane umownie mityczną i naukową, przy tym budowane są one paralelnie, bez jakiegokolwiek kontaktu ${ }^{3}$. Pomimo niechęci do stworzenia platformy wspólnej debaty, prowadzone dyskusje wzbudzały wiele kontrowersji i emocji, dotyczyły bowiem kwestii fundamentalnych, a akceptacja jednej z wymienionych tutaj opcji miała określone konsekwencje na różnych płaszczyznach życia społecznego, wpływała też na indywidualne światopoglądy.

${ }^{1}$ M. Bobrownicka, Patologie tożsamości narodowej w postkomunistycznych krajach słowiańskich, Kraków 2006, s. 5-6.

2 J. Assmann, Kultura pamięci, przeł. A. Kryczyńska-Pham [w:] Pamięć zbiorowa i kulturowa. Współczesna perspektywa niemiecka, red. M. Saryusz-Wolska, Kraków 2009, s. 84.

${ }^{3}$ R. Chmel, Zamknięta Stowacja versus społeczeństwo otwarte, przeł. T. Grabiński [w:] idem, Kompleks słowacki. Eseje, przeł. M. Bystrzak, T. Grabiński, Kraków 2014, s. 47. 
Kierunek, w jakim przebiegało słowackie myślenie o pożądanym dla aktualnych wyzwań kształcie tradycji, zależał od wielu czynników i zmieniał się w czasie; w niektórych okresach dyskusje poświęcone tożsamości narodowej, w tym próby konstruowania kryteriów, jakie , prawdziwy Słowak” spełniać powinien, były bardzo ożywione, w innych zagadnienia tożsamościowe wypierane były przez problematykę ekonomiczną, chociaż nigdy nie znikały całkowicie z debaty publicznej. Trudności gospodarcze i społeczne, znalezienie rozwiązań, które zapobiegłyby wzrastającemu zubożeniu społeczeństwa, bezrobociu itd., interesowały zresztą społeczeństwo słowackie w większym stopniu niż, uważane za abstrakcyjne, rozważania dotyczące narodowej i kulturowej autoidentyfikacji ${ }^{4}$. Refleksje i próby uporządkowania najważniejszych elementów słowackiego imaginarium podejmowano głównie w kręgach akademickich, a jednocześnie wybrane symbole, konstrukcje i narracje, jak już wspomniałem, były często instrumentalizowane i wykorzystywane jako oręż w bieżącej walce politycznej, aktualizując historyczne traumy i resentymenty, przede wszystkim związane z relacjami słowacko-węgierskimi, i służyły odsunięciu na plan dalszy poważnej, merytorycznej dyskusji o możliwościach poprawy poziomu życia obywateli, którzy, odreagowując poczucie zagubienia i braku stabilności, nostalgicznie zaczęli wspominać poprzedni ustrój ${ }^{5}$.

Działania zmierzające do wyznaczenia określonym tradycjom konstytutywnej roli w obrębie pamięci zbiorowej, a tym samym wybór strategii, które pozwalałyby zrozumieć teraźniejszość i projektować pożądaną przyszłość, przeprowadzane były w okresie transformacji na kilku płaszczyznach. Proponuję wyróżnić trzy, moim zdaniem, podstawowe wątki, jakie w słowackim dyskursie pojawiły się w omawianym okresie: po pierwsze - istotne dla budowania nowego ustroju państwa próby odnalezienia w przeszłości tradycji demokratycznych; po drugie - sposoby lektury i oceny epizodu powstałego z inspiracji Hitlera tzw. państwa słowackiego (1939-1945), jedynego narodowego państwa Słowaków przed 1993 r.; po trzecie - analizy charakteru i oceny funkcjonalności w nowej sytuacji społeczno-politycznej elementów, które kluczową rolę odegrały w dziewiętnastowiecznych procesach konstruowania słowackiej tożsamości. W prezentowanych rozważaniach skupię się na trzeciej spośród wyróżnionych linii słowackiego myślenia o przeszłości; zanim jednak przejdę do dokład-

${ }^{4}$ Rudolf Chmel zwraca uwagę na jeszcze jeden czynnik wpływający na duży stopień obojętności społeczeństwa wobec kwestii interpretacji narodowej tradycji: „Opinia publiczna, która aż tak bardzo nie interesuje się tymi zagadnieniami, właściwie nie odczuwa deficytu tego dyskursu. W czasach konsumpcji, komercji, telenowel i innego kiczu nie jest to aż tak zaskakujące. [...] Kiedy sensem życia stały się konsumpcja i zysk, pytanie o sens historii staje się bezcelowe" -ibidem, s. 47.

${ }^{5}$ „Według badań liczba ludzi, którzy uważają poprzedni ustrój za lepszy niż dzisiejsza demokracja, raczej się nie zmienia - już od lat jest ich około pięćdziesiąt procent" - pisał w 2002 r. Martin M. Šimečka w eseju poświęconym słowackiej nostalgii za komunizmem. Zob. M. M. Šimečka, 110 konarów. Realny socjalizm i płynqce zeń nauki, przeł. L. Engelking [w:] Nostalgia. Eseje o tęsknocie za komunizmem, red. F. Modrzejewski, M. Sznajderman, Wołowiec 2002, s. 141. 
niejszego omówienia współczesnych interpretacji odrodzeniowego dziedzictwa, w skrótowej formie przedstawię najważniejsze problemy związane $\mathrm{z}$ dwoma pierwszymi zagadnieniami.

Odwołanie do tradycji demokratycznego państwa w przypadku słowackim mogło być tylko jedno - międzywojenna I Republika Czechosłowacka, której system oparty był głównie na koncepcjach Tomáša Garrigue’a Masaryka. Przekonanie, że aktualizacja najważniejszych elementów tej tradycji doprowadzi, niejako „automatycznie”, do demokratycznej przemiany, nie tylko w oficjalnych deklaracjach, ale przede wszystkim na płaszczyźnie funkcjonowania struktur państwowych oraz świadomości społecznej, było jednak iluzją. Trafnie komentuje to Dušan Kováč:

Jeżeli społeczeństwo, zarówno na ziemiach czeskich, jak i na Słowacji, skandowało w 1989 roku hasło „powrotu do demokracji”, domagało się mniej więcej powrotu do pierwszej republiki, a dokładniej, pluralizmu sceny politycznej i powszechnego prawa wyborczego. Problem polegał na tym, że koncepcja demokracji jako stylu życia, komunikacji i jako typu kultury politycznej w międzyczasie w dojrzałych demokracjach rozwinęła się i powrót do przeszłości był nie tylko niemożliwy, ale w zasadzie nie był nawet pożądany. [...] Listopad 1989 roku nie był i nie mógł być ani powrotem do demokracji, ani wprowadzeniem demokracji. Demokracji bowiem nie można - w odróżnieniu od systemu totalitarnego - wprowadzić, ale musi być ona kultywowana w codziennej komunikacji ${ }^{6}$.

Stabilizacja systemu demokratycznego będzie w słowackim życiu politycznym trwała stosunkowo długo; istotnymi przeszkodami w konsekwentnie przeprowadzonej zmianie systemowej były między innymi autorytarny charakter rządów Vladimíra Mečiara, nieufność obywateli wobec państwa, nadużywanie władzy w sferze gospodarki, chociażby przy okazji procesów prywatyzacyjnych. Pamięć o tradycjach międzywojennej Czechosłowacji pozostała pamięcią „podręcznikową” i właściwie nie odegrała żadnej istotnej roli w formowaniu się nowego kształtu życia polityczno-społecznego.

Ocena fragmentów słowackiej historii, które upłynęły pod znakiem dwudziestowiecznych totalitaryzmów, była wielkim wyzwaniem i dyskusje dotyczące tych problemów właściwie trwają do dzisiaj. Dotyczy to zwłaszcza okresu II wojny światowej, sposobu funkcjonowania tzw. klerofaszystowskiej Republiki Słowackiej, w tym przyzwolenia władz na eksterminację Żydów (zgodnie z obowiązującym prawem - wzorowanym na ustawach norymberskich tzw. kodeksem żydowskim z 1941 r.), w wyniku czego zamordowanych zostało około 71 tysięcy obywateli żydowskiego pochodzenia $^{7}$, bezwzględnego eliminowania przeciwników politycznych itd. Pomimo tych,

${ }^{6}$ D. Kováč, November '89 v dejinách Slovenska [w:] Kde sme? Mentálne mapy Slovenska, red. M. Bútora, M. Kollár, G. Mesežnikov, Z. Bútorová, Bratislava 2010, s. 22-23. Fragmenty tekstów słowackich, o ile nie podano inaczej, w przekładzie autora artykułu.

${ }^{7}$ B. Keff, Antysemityzm. Niezamknięta historia, Warszawa 2013, s. 170. 
opartych na materiałach źródłowych faktów, część historyków, zwłaszcza emigracyjnych, próbowała w powstaniu Republiki Słowackiej w 1993 r. dostrzec pewne paralele z okresem 1939-1945 ${ }^{8}$. Ivan Kamenec tendencję tę charakteryzuje w następujący sposób:

[Powstanie Republiki Słowackiej w 1993 r. - R. M.] niektóre, na ogół marginalne prądy ideowe na Słowacji, ale także część słowackiej emigracji politycznej i wielu obywateli w kraju naiwnie nazywało (lub taką przynajmniej żywiono nadzieję) „cichym” powrotem do ideałów państwa $\mathrm{z}$ lat 1939-1945 w warunkach demokratycznych, tym samym robiąc pierwszy oficjalny krok w kierunku całkowitej lub przynajmniej częściowej rehabilitacji tego reżimu i jego reprezentantów. Twórcami względnie zwolennikami takich tendencji byli nie tylko politycy, publicyści czy historycy, ale również świadkowie, którzy istniejące $\mathrm{w}$ czasie wojny państwo słowackie oceniają przez pryzmat osobistych pozytywnych, negatywnych i traumatyzujących przeżyć, ówczesnych i późniejszych poglądów 9

Konstruowanie pozytywnego obrazu Słowacji w czasie wojny opierało się na kilku przesłankach, spośród których do najważniejszych zaliczyć można: idealizację państwa ze względu na sam fakt jego istnienia jako pierwszego państwa słowackiego, eksponowanie intensywnego rozwoju kultury i nauki (oczywiście, w granicach wyznaczanych przez obowiązującą ideologię), przedstawianie porozumienia z Hitlerem jako realizacji strategii „mniejszego zła” - jedynej możliwości przetrwania narodu, który, zgodnie z ówczesnymi prognozami, nie zgadzając się na sojusz z III Rzeszą, zostałby podporządkowany sąsiadom i włączony w obręb ich struktur państwowych, prezentowanie zagłady obywateli żydowskich jako jednoznacznej winy Niemców ${ }^{10}$ (przypomnijmy, że rząd słowacki za każdego obywatela żydowskiego wywiezionego do obozu uiszczał opłatę 500 marek, która oficjalnie miała pokryć koszty przesiedlenia i nauki zawodu). Oczywiście powstawały i nadal powstają prace historyczne krytycznie omawiające tzw. państwo słowackie, organizowane są spotkania edukacyjne, na poziomie aktywności społecznej sprzeciw wobec jego idealizacji widoczny jest

${ }^{8}$ M. Michela, Pripomínanie a kanonizovanie minulosti. Úvaha na margo niektorých diskusií o dejinách Slovenska, http://www.forumhistoriae.sk/documents/10180/39392/Michela.pdf (dostęp: 12.05.2013).

${ }^{9}$ I. Kamenec, Slovenská republika 1939-1945 a jej mýty [w:] Mýty naše slovenské, red. E. Krekovič, E. Mannová, E. Krekovičová, Bratislava 2005, s. 181.

${ }^{10}$ „Odpowiedzialność za tragedię, za wymordowanie ponad dwóch trzecich tutejszych obywateli żydowskich alibistycznie przenosi się na nazistowskie Niemcy i, co jest najbardziej cyniczne, także na same ofiary prześladowań, które podobno «mają dziedziczną cechę nie tylko wywoływania zawiści i nienawiści, ale też stwarzania sobie wrogów tam, gdzie jest to niepotrzebne». Na podstawie tej ksenofobicznej przesłanki emigracyjny autor (F. Vnuk) formułuje taki wniosek: «Jeżeli istniał naród, który miał powody wysiedlić ze swojego terytorium Żydów, był nim naród słowacki. Jedyny, który miał taki powód»" - I. Kamenec, Trauma holokaustu. Historický alebo morálny problem? [w:] Slovenská otázka dnes. Výber textov z časopisu OS 1997-2006, red. L. Szigeti, Bratislava 2007, s. 207. 
chociażby podczas antyfaszystowskich inicjatyw, niemniej tendencja do jego gloryfikacji stale jest obecna; 13 marca, w dniu rocznicy powstania Republiki Słowackiej, odbywa się tradycyjny Pochód za naród, podczas którego składany jest hołd „męczennikowi", księdzu Jozefowi Tisie (skazanemu za zbrodnie wojenne i straconemu w 1947 r.), w słowackich miejscowościach znaleźć można tablice pamiątkowe czy nazwy ulic upamiętniające kluczowe postaci reżimu (prezydent Jozef Tiso, minister spraw zagranicznych Ferdinand Durčanský), a przedstawiciele Kościoła nadal podejmują starania o beatyfikację spiskiego biskupa Jána Vojtaššáka, bagatelizując jego aprobatę dla antyżydowskiego ustawodawstwa i udział $\mathrm{w}$ aryzacji ${ }^{11}$. Zagadnienie interpretacji sytuacji Słowacji w czasie II wojny światowej niewątpliwie jeszcze wielokrotnie będzie podejmowane przez historyków reprezentujących różne opcje światopoglądowe i, pomimo oczywistych dowodów świadczących o totalitarnym charakterze tzw. państwa słowackiego konsensusu trudno się spodziewać, zwłaszcza w obliczu ciągłej obecności, zresztą nie tylko w słowackim życiu społecznym i politycznym, pierwiastków nacjonalistycznych.

Wspomniane powyżej tradycje i sposoby ich rozumienia stanowią jedynie niewielki, w moim przekonaniu jednak bardzo istotny wycinek współczesnej słowackiej refleksji o przeszłości, refleksji, która w pewnej mierze opierać się może jeszcze na tzw. żywej pamięci społecznej; odczytania oraz oceny wydarzeń międzywojnia i okresu wojennego odwołują się bowiem nie tylko do oficjalnych dokumentów, ale również przekazywanych wspomnień i świadectw. Z inną sytuacją mamy do czynienia, gdy współczesna refleksja dotycząca tożsamości narodowej bazuje na zbiorze symboli, mitów, narracji, jakie powstały i ustabilizowały się w czasie słowackich dziewiętnastowiecznych procesów emancypacyjnych. Funkcja tych elementów w momencie definiowania „słowackości”, budowania wspólnoty narodowej, przy nieustającym poczuciu niepewności i zagrożenia dla bytu narodowego, była niezwykle istotna, pozwoliła bowiem stworzyć warunki zbiorowej integracji i komunikacji ${ }^{12}$. Wydawać by się mogło, że w sytuacji niepodległego, z definicji demokratycznego, zabiegającego o uczestnictwo w strukturach europejskich państwa, odrodzeniowe konstrukcje traktowane będą z dystansem i rozumiane jako zjawiska ograniczone do konkretnego czasu, z przypisaną im konkretną rolą. Okazało się jednak, że stworzone głównie przez romantyków wyobrażenia o narodowym charakterze, historycznych doświadczeniach itd. również w nowych warunkach dla niektórych środowisk odznaczają się atrakcyjnością i można je w określony sposób wykorzystać.

Analizując najważniejsze wątki tworzonych po 1989 r. słowackich narracji tożsamościowych, które odwoływały się do dziedzictwa odrodzenia narodowego, stwier-

${ }^{11}$ M. Vrzgulová, Vykročili sme. Historická pamät’ a kritická reflexia minulosti [w:] Odkial' a kam. Dvadsat' rokov samostatnosti, red. M. Bútora, G. Mesežnikov, Z. Bútorová, M. Kollár, Bratislava 2013, s. $179-180$.

${ }^{12}$ Zob. R. Majerek, Pamięć - mit - tożsamość. Słowackie procesy autoidentyfikacyjne w okresie odrodzenia narodowego, Kraków 2011. 
dzić można, że szczególnie istotne miejsce zajęły one w okresie funkcjonowania dwóch gabinetów: Vladimíra Mečiara oraz Roberta Fico. Charakter rządów Mečiara, który po powstaniu Republiki Słowackiej dwukrotnie pełnił funkcję premiera (1 stycznia 1993-14 marca 1994, 13 grudnia 1994-30 października 1998), wyznaczały autorytaryzm, populizm, pomijanie zasad demokracji, brak szacunku dla praw obywatelskich, klientelizm w życiu publicznym i gospodarczym, kontrola mediów, nietolerancja wobec mniejszości narodowych. Ten styl władzy, słusznie nazwany przez Milana Zemkę modelem postkomunistycznej „demokratury”"13, doprowadził do wyraźnej polaryzacji społeczeństwa oraz problemów na arenie międzynarodowej, przede wszystkim podczas rozmów dotyczących przystąpienia Słowacji do Unii Europejskiej. Robert Fico, zwłaszcza w czasie pierwszej kadencji (4 lipca 2006-8 lipca 2010) ${ }^{14}$, przejmując większość elektoratu partii Mečiara, Ruchu na rzecz Demokratycznej Słowacji oraz zyskując zwolenników w szeregach nacjonalistycznej Słowackiej Partii Narodowej, również bazował na populizmie, ,na połączeniu nostalgii za komunizmem i nacjonalizmu" ${ }^{15}$, chociaż w jego przypadku wyraźniej zaznaczała się także proeuropejska orientacja. Jak wspomniałem, podczas rządów tych dwóch polityków w obrębie słowackiego dyskursu tożsamościowego na znaczeniu zyskały odwołania do zmitologizowanych konstrukcji odrodzeniowych, którym, wykorzystując dostępne władzy kanały dystrybucji wiedzy, próbowano nadać status obowiązującej ideologii. Działania te spotykały się, oczywiście, ze sprzeciwem części społeczeństwa oraz krytyką ze strony niektórych, umownie mówiąc, liberalnych środowisk intelektualnych; głosy te jednak zazwyczaj były ignorowane lub, w skrajnych przypadkach, traktowane jako swego rodzaju próby zamachu na słowackość.

Elementy odrodzeniowego paradygmatu myślenia aktualizowano na gruncie tekstów literackich, w pracach o ambicjach naukowych, dokumentach prawnych, publicystyce, podczas uroczystości państwowych. Podobnie jak w XIX w., w sposobie rozumienia i prezentowania przeszłości fakty historyczne były odpowiednio selekcjonowane, wpisywane w pożądaną ideologię, stylem odbioru tak budowanego odczytania tradycji był odbiór oparty na emocjach i wierze, chociaż, oczywiście, wszystkie zmitologizowane konstrukcje przedstawiane były jako wyniki obiektywnego poznania. Przywołajmy kilka charakterystycznych przykładów, potwierdzających obecność tej tendencji w słowackiej przestrzeni kulturowej.

Jedną z najważniejszych narracji, popularyzowanych po podziale Czechosłowacji, stał się mit „starego narodu i młodego państwa”, mający niejako kompensować kompleks związany z brakiem we wcześniejszej historii własnego, znaczącego organizmu politycznego (chociaż za przykład słowackiej tradycji państwowej będą uzna-

${ }^{13}$ M. Zemko, Moderný politický národ [w:] Slovenská otázka dnes..., s. 191.

${ }^{14}$ Robert Fico ponownie objął stanowisko premiera 4 kwietnia $2012 \mathrm{r}$.

${ }_{15}$ J. Buzalka, Od štátu slovenského národa k multietnickej demokracii? [w:] Odkial' a kam..., s. 165 . 
wane Wielkie Morawy), a przy tym budować poczucie dumy narodowej. Aspekt perswazyjno-edukacyjny widoczny jest na przykład w adresowanych głównie do młodych czytelników książkach historycznych Milana Ferki (dodajmy, w latach 19941998 dyrektora Sekcji Języka Państwowego i Piśmiennictwa Narodowego przy Ministerstwie Kultury Republiki Słowackiej) oraz pracach o charakterze podręcznikowym $^{16}$, kolportowanych w dużych nakładach do słowackich szkół ${ }^{17}$. Potrzeba ciagłego uzasadniania własnego istnienia, podobna w swej retoryce do barokowych i odrodzeniowych ,pochwał i obron” narodu, eksponowanie jego mitycznych początków, przywoływanie twierdzeń o wyjątkowości języka słowackiego oraz niezwykłości „odwiecznej przestrzeni między Tatrami i Dunajem”, podkreślanie wyjątkowej atrakcyjności ziem słowackich, czego potwierdzeniem ma być odnalezienie czaszki neandertalczyka w okolicach Popradu, przywoływanie kontaktów przodków Słowaków z Imperium Rzymskim, twierdzenie, jakoby Słowacy zyskali świadomość odrębności etnicznej od Morawian za czasów panowania Mojmira (czyli w IX w.) - wszystkie elementy fantastycznej narracji historycznej miały przekonać czytelników o długich i pełnych istotnych wydarzeń dziejach Słowacji, terytorium szczególnego, stanowiącego serce Europy ${ }^{18}$. Dodajmy, że określenie „Słowacja” stosowane jest w odniesieniu do każdego okresu historycznego, co stwarzać ma przekonanie o nieprzerwanym kontinuum narodowej historii. Analogiczną strategię dostrzec można również w pracy Staré povesti slovenské (Dawne opowieści stowackie, 1990), w której Ferko „zrekonstruował" dzieje słowackie od II w. n.e. (okres Imperium Rzymskiego), poprzez istnienie tzw. państwa Samona, po czasy wielkomorawskie i stopniowe włączanie obszaru Słowacji w obręb Królestwa Węgierskiego ${ }^{19}$.

Milan Ferko w swojej wizji słowackich dziejów nie był odosobniony; preferencję dla ich mitycznego ujęcia wykazywało jeszcze kilku historyków, między innymi Milan Stanislav Durica, znany przede wszystkim z książki Dejiny Slovenska a Slovákov (Historia Słowacji i Słowaków, 1995). Autor historię Słowaków rozumie jako trwającą od stuleci walkę o własne państwo, jako przykłady słowackich struktur państwowych podaje tzw. państwo Samona, Wielkie Morawy, nazwane „Rzeszą Słowacką”, próby wydzielenia autonomicznego terytorium na ziemiach słowackich podejmowane przez zbuntowanych wobec władzy centralnej przedstawicieli stanu szlacheckiego (Mateusz Csák, Imre Thököly, Franciszek II Rakoczy) także uznaje za formy słowackiej państwowości, natomiast powstanie Republiki Słowackiej, zarówno w 1939, jak i 1993 r., uznaje za ukoronowanie i zakończenie procesu emancypacyjnego. Praca Duricy prawdopodobnie nie wzbudziłaby tak wielkiego sprzeciwu w środowiskach

${ }^{16}$ Na przykład M. Ferko, R. Marsina, L. Deák, Starý národ-mladý štát. Prehl'ad slovenských dejín pre školy, Bratislava 1994.

${ }^{17}$ P. Zajac, Literarizácia slovenských mýtov na konci dvadsiateho storočia, „Slovenská literatúra” 1998, nr 5, s. 343.

${ }^{18}$ M. Ferko, R. Marsina, L. Deák, Starý národ ..., s. 4.

${ }^{19}$ M. Ferko, Staré povesti slovenské, Bratislava 2004. 
historyków, gdyby nie fakt, że Ministerstwo Szkolnictwa podjęło w 1996 r. decyzję o jej dystrybucji z własnych środków do szkół podstawowych, zalecając korzystanie z niej podczas lekcji historii. W liście skierowanym do minister Evy Slavkovskiej przedstawiciele Instytutu Historii Słowackiej Akademii Nauk pisali między innymi:

Wybór faktów jest często przypadkowy, ale przede wszystkim tendencyjny, a ich interpretacja pozostaje często $\mathrm{w}$ zdecydowanej sprzeczności z aktualnym stanem wiedzy historycznej. Ożywia stare, dawno porzucone mity, zawiera wiele kłamstw i mistyfikacji ${ }^{20}$.

Do listu dołączona została szczegółowa analiza, w której wykazano błędy i przekłamania, jakie się w książce znalazły. Ostre słowa krytyki zabrzmiały także podczas debaty poświęconej publikacji; Dušan Kováč stwierdził:

To, co Ďurica proponuje opinii publicznej, to powrót historiografii do etapu przednaukowego. Jakbyśmy chcieli cofnąć fizykę do czasów sprzed Einsteina lub jeszcze dalej w przeszłość. W tym kontekście rozumiem, dlaczego ta książka powstała, dlaczego istnieje tu grupa ludzi, którzy chcą to prezentować, coś udowadniać, czegoś bronić. Są opętani przez wyznawaną ideologię i nie uświadamiają sobie, że współczesna Słowacja jej nie potrzebuje ${ }^{21}$.

W rezultacie protestów krajowych, a także zaleceń z Brukseli, publikacja była bowiem częściowo finansowana ze środków Unii Europejskiej, książkę wycofano ze szkół, niemniej sama próba jej promowania w takiej formie dobitnie pokazuje, jak rząd Mečiara wspierał ideologicznie jednoznaczny, oparty na przekłamaniach obraz narodowej tradycji (dotyczyło to nie tylko starszych dziejów, lecz także m.in. apologetycznej prezentacji okresu 1939-1945). Najogólniej tendencję tę określić można jako „dążenie do kanonizacji radykalnej formy nacjonalistyczno-romantycznego dys-

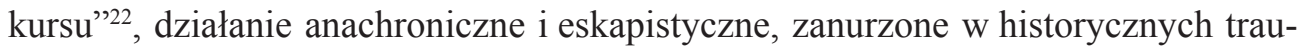
mach i kompleksach, wspierające model społeczeństwa zamkniętego, zupełnie nieodpowiadający wyzwaniom młodej słowackiej demokracji.

Oficjalnie pozycję mitu, zakładającego kontinuum rozwojowe narodu oraz terytorialną koncepcję dziejów, potwierdziła preambuła Konstytucji Republiki Słowackiej:

My, naród słowacki, pamiętając o dziedzictwie politycznym i kulturalnym swoich przodków i o stuleciach doświadczeń ze zmagań o byt narodowy i własną państwowość, w sensie dziedzictwa duchowego Cyryla i Metodego i historycznego spadku Wielkiej Morawy, wychodząc z naturalnego prawa narodów do samookreślenia, wspólnie z członkami mniejszości narodowych i grup etnicznych, żyjących na terytorium Republiki Słowackiej [...],

${ }^{20}$ Slovenski historici o knihe, „Kritika \& kontext” 1997, nr 2-3, s. 34.

${ }^{21}$ D. Kováć, głos w dyskusji Okruhlý stôl. Slovensko a fenomén Ďurica, „Kritika \& kontext” 1997, nr 2-3, s. 5.

${ }^{22}$ M. Michela, Pripomínanie a kanonizovanie... 


\section{zatem my, obywatele Republiki Słowackiej uchwalamy \\ za pośrednictwem naszych przedstawicieli tę konstytucję $e^{23}$.}

Przytoczony fragment pokazuje kilka istotnych kwestii: $\mathrm{w}$ dokumencie państwowym o najwyższej randze usankcjonowane zostaje przeświadczenie o długich dziejach narodu, w nieuzasadniony sposób w przeszłości sytuowane są tendencje emancypacyjne, ponadto preambuła tworzy swego rodzaju hierarchię ważności mieszkańców istniejącego państwa, opartą na preferencji dla czynnika narodowego kosztem wartości obywatelskich. Cytując antropologa społecznego, Juraja Buzalkę:

Najważniejszy jest „naród słowacki” jako podmiot zbiorowy, który łaskawie pozwala nie-Słowakom istnieć w państwie. [...] Obywateli, którzy nie są częścią uprzywilejowanego narodu „państwowotwórczego”, preambuła zmieniła w nielojalną sitwę ${ }^{24}$.

Ustalonej „oficjalnej mitologii państwowej”25 obywatele powinni się bezdyskusyjnie podporządkować; jako obowiązującą prawdę powinny ją przyswajać młode pokolenia, czemu służyć miało zalecenie Ministerstwa Szkolnictwa, aby uczniowie uczyli się tekstu preambuły na pamięć. Proponowane zapisy wywołały głosy krytyki nie tylko wśród mniejszości węgierskiej, której przedstawiciele głosowali przeciwko przyjęciu konstytucji, lecz także w niektórych słowackich środowiskach intelektualnych. Próby podważenia zasadności czy przydatności takiej formy rozumienia słowackiej drogi do samostanowienia i kształtu nowego państwa traktowano z właściwą kulturze totalizującego monologu ignorancją, dyskredytując sceptycznie i krytycznie nastawionych obywateli jako „zdrajców narodu słowackiego”, ewentualnie marksistów ${ }^{26}$.

Sposoby rozumienia tradycji, jak widać z przytoczonych przykładów, są niezwykle podatne na manipulacje i bardzo szybko stać się mogą ,pożywką dla ideologii i tworzywem populistycznej demagogii społecznej" 27 , a w rezultacie prowadzić do odnowienia dawnych konfliktów narodowościowych. Na Słowacji problem ten dotyczył przede wszystkim relacji z mniejszością węgierską, zamieszkującą południową część kraju, oraz stosunku do Romów. O ile jednak trudności w znalezieniu form współistnienia ze społecznością romską i niechęć, a czasami również agresja wobec jej przedstawicieli uzasadniane były aktualnymi aspektami ekonomicznymi i kulturowymi (przekonanie o nieuzasadnionym wspieraniu finansowym romskich rodzin, wskazywanie na brak inicjatyw zmierzających do integracji społecznej, wysoki stopień

${ }^{23}$ Konstytucja Republiki Stowackiej, oprac. i przeł. S. Sagan, Katowice 1993, s. 31.

${ }^{24}$ J. Buzalka, O przyszłości pewnej koncepcji, przeł. M. Bystrzak, „Herito” 2012, nr 9, s. 43.

${ }^{25}$ B. Ferenčuhová, Zmieri sa Slovensko so svojím nacionalizmom? [w:] Slovenská otázka dnes..., s. 174.

${ }^{26}$ Ibidem

${ }^{27}$ M. Bobrownicka, Patologie tożsamości narodowej..., s. 11. 
przestępczości), o tyle konflikty z Węgrami wyraźnie nawiązywały do przeszłych doświadczeń, były swego rodzaju pochodną rozumienia własnej historii i towarzyszących jej mitów (mitu wielkomorawskiego oraz mitu o tysiącletniej niewoli).

Stosunek władz do Węgrów, który był jedną z przyczyn zahamowania na pewien czas procesu przystapienia Słowacji do Unii Europejskiej, znajdował odzwierciedlenie zarówno na płaszczyźnie propozycji legislacyjnych (przede wszystkim dotyczących zakresu używania języka węgierskiego w instytucjach państwowych, w nazwach miejscowości), jak i symbolicznej. Przykładów działań zmierzających do podkreślenia integralności terytorium słowackiego wymienić można wiele, prawdopodobnie najbardziej wymownym były wydarzenia związane z postawieniem w 2003 r. w Komarnie - mieście ze względów historycznych posiadającym zdecydowanie węgierski charakter, zamieszkanym współcześnie przez liczną mniejszość węgierską (według danych z 2011 r. około 53\%), pomnika Cyryla i Metodego. Inicjatywa powstała w Macierzy Słowackiej, najstarszej słowackiej instytucji życia narodowego, której przedstawiciele zwrócili się do władz miasta z prośbą o wyznaczenie odpowiedniego miejsca, w którym pomnik mógłby stanąć. Wszystkie propozycje lokalizacji, które pojawiły się w odpowiedzi na tę prośbę, uznane zostały za niezadowalające, w rezultacie problem rozwiązano, umieszczając pomnik, mimo protestów władz miasta, na fasadzie budynku miejscowego oddziału Macierzy. W 2010 r. niemal czterometrowy pomnik przeniesiono w nowe miejsce, na środek ronda, co obecny na uroczystości wraz ze świtą ministrów premier Fico uznał za wydarzenie symboliczne, bowiem w tym miejscu, jak stwierdził, krzyżują się drogi do Bratysławy, Budapesztu i Nowych Zamków. Miasto, którego burmistrz zresztą na odsłonięcie pomnika nie został zaproszony, protestowało, wskazując na względy bezpieczeństwa, co jednak nie przyniosło żadnego efektu, bowiem wybrane miejsce to część drogi krajowej, dlatego też opinia władz miasta nie miała żadnej mocy prawnej.

Obserwator z zewnątrz, który nie zna charakteru relacji słowacko-węgierskich, całe zdarzenie mógłby ocenić jako nieco infantylną, a biorąc pod uwagę okoliczności - nawet groteskowa, niemniej neutralną formę kultywowania tradycji. Inaczej kwestia ta wygląda z perspektywy osoby funkcjonującej w tym środowisku. Daniela Kapitáňová, pisarka i mieszkanka Komarna, komentowała:

[...] Każdy, kto tutaj żyje, a właściwie każdy, kto mieszka na Słowacji, wie, że chodziło tutaj o coś zupełnie innego niż wyrażenie szacunku chrześcijańskim świętym z Sołunia. Chodziło tutaj o oznakowanie terytorium własnymi flagami. [...] Tutaj rzeźby nie są eksponowane jako dzieła sztuki, ale ustawia się je jak makiety czołgów na mapie działań wojennych w sztabie generalnym. Informują one o zdobytym terytorium ${ }^{28}$.

Inicjatywa, działającej przy wsparciu władzy, Macierzy Słowackiej - instytucji, która ,stwarza wizję narodu, któremu zagrażają Węgrzy i mniejszość węgierska w Sło-

${ }^{28}$ D. Kapitáňová, Ich Komarno a môj Trianon [w:] Slovenská otázka dnes..., s. 395. 
wacji, oraz występuje przeciw antynarodowym, zbyt mało gorliwym i jeszcze mniej zaangażowanym Słowakom" ${ }^{29}$ wpisuje się w znaną i praktykowaną chociażby w okresie komunizmu - strategię symbolicznego zawłaszczania terytorium, niepotrzebnie przywołując dawne resentymenty i kreując nowe antagonizmy. Niestety, temu właśnie często służą aktualne odwołania do najważniejszych, ustabilizowanych w XIX w., znaków słowackiej tożsamości narodowej: języka oraz terytorium (krainy) ${ }^{30}$. Porównanie historycznego i współczesnego sposobu ich wykorzystania i funkcjonowania pokazuje, jak ten sam element wykorzystany być może do różnych celów ideologicznych oraz jak różne konsekwencje może przynosić. Określone symbole i narracje w okresie słowackiego odrodzenia narodowego były elementami nacjonalizmu o obliczu wyzwoleńczym, służącemu emancypacji, natomiast dzisiaj, bezkrytycznie powtarzane $\mathrm{i}$ instrumentalizowane, przyczyniać się mogą jedynie do kształtowania nacjonalizmu antydemokratycznego i antyliberalnego, nazywanego również nacjonalizmem integralnym ${ }^{31}$.

Konieczność krytycznego przewartościowania wpisujących się w ramy myślenia mitycznego wyobrażeń jest jednak coraz wyraźniej na Słowacji obecna, tworząc alternatywę dla spetryfikowanych form rozumienia tradycji. Działania te zakładają przede wszystkim analizę kontekstów powstania zmitologizowanych przekazów oraz potrzeb, na jakie odpowiadały, a także wykazanie ich konstruktywistycznego, niezwiązanego z kategoriami „,prawdziwości”, „oczywistości”, „naturalności” charakteru.

Krytyczne spojrzenie na ,słowackie uwikłanie w mit”, próby rewizji utrwalonych konstrukcji i stereotypów przyniosły już wiele interesujących efektów, między innymi publikację Mýty naše slovenské (Nasze stowackie mity) ${ }^{32}$, przygotowaną w ramach projektu Słowackiej Akademii Nauk Kolektivne identity v moderných spoločnostiach Európy. Procesy konštruovania, reprodukcie a transformácie kolektívnych kategórií a identit (Tożsamości zbiorowe w nowoczesnych spoleczeństwach Europy. Procesy konstruowania, odtwarzania i transformacji zbiorowych kategorii i tożsamości). W tomie tym znajdziemy przegląd najważniejszych słowackich tradycji - analizy mitów założycielskich, kompleksu mitów związanych z okresem Wielkich Moraw, martyrologicznego mitu ofiary i tysiącletniej niewoli, mitów językowych, omówienie naro-

${ }^{29}$ R. Chmel, Dwie Stowacje, przeł. M. Bystrzak, „Herito” 2012, nr 9, s. 31.

${ }^{30}$ Te pojęcia, obok „ludu” i „środka”, Dušan Kováč wymienia jako najistotniejsze w procesie kształtowania się słowackiej tożsamości narodowej. Zob. D. Kováč, Słowacka tożsamość w procesie historycznym, przeł. J. Bakalarz [w:] Kim sq Słowacy. Historia. Kultura. Tożsamość, red. J. Purchla, M. Vášáryová, Kraków 2005, s. 57-65.

${ }^{31}$ J. Szacki, O narodzie i nacjonalizmie, „Znak” 1997, nr 3, s. 28. Warto w tym kontekście przywołać wypowiedź premiera Fico, wygłoszoną 26 lutego 2013 r. na konferencji z okazji 150-lecia Macierzy Słowackiej: „Naszego niezależnego państwa nie zakładaliśmy dla mniejszości, pomimo naszego dla nich szacunku, ale przede wszystkim dla słowackiego państwowotwórczego narodu, bowiem Słowacy w byłej Czechosłowacji nie mogli rozwinąć wszystkich swoich zdolności i talentów" - cyt. za: J. Buzalka, Od štátu slovenského národa..., s. 161.

${ }^{32}$ Mýty naše slovenské. 
dowych i państwowych symboli, narracji o najważniejszych wydarzeniach w życiu narodu, wreszcie interpretację zmitologizowanych biografii wybranych postaci słowackich dziejów, takich jak między innymi Milan Rastislav Štefánik, Andrej Hlinka, Jozef Tiso, Gustáv Husák. Podkreślić warto, że w przedsięwzięcie wpisana wyraźnie była funkcja edukacyjna, o czym świadczy opublikowanie, jeszcze przed wydaniem książki, wybranych tekstów w popularnym dzienniku „SME”.

Nowa jakość spojrzenia na tradycję narodową wielokrotnie pojawiała się także w eseistyce, głównie w tekstach publikowanych w czasopiśmie „OS” oraz książkach z serii „Domino” wydawanych przez wydawnictwo Kalligram. Autorzy, tacy jak między innymi L’ubomír Lipták, Rudolf Chmel, Peter Zajac, L'ubomír Ďurovič, Pavol Lukáč, w swoich pracach konsekwentnie starali się stworzyć płaszczyznę dialogu dotyczącego narodowej samoświadomości, wskazując na ułomności dominujących strategii dyskursu tożsamościowego. Warto wreszcie wspomnieć tomy przygotowane przez Instytut Spraw Publicznych: Kde sme? Mentálne mapy Slovenska (Gdzie jesteśmy? Mentalne mapy Słowacji, 2010), Odkial' a kam. 20 rokov samostatnosti (Skad i doką. Dwadzieścia lat niezależności, 2013), w których przedstawiciele różnych dyscyplin nauki (politologii, socjologii, ekonomii, językoznawstwa, historii sztuki, muzykologii itd.) zaprezentowali wyniki badań nad przemianami poszczególnych sfer życia Słowacji od czasów aksamitnej rewolucji.

Wspomniane inicjatywy, subiektywnie wybrane jako najistotniejsze, sprawiaja, że obraz słowackiej przeszłości staje się coraz bogatszy, a przy tym potwierdzają odchodzenie od izolacjonistycznej polityki kulturalnej i etnocentrycznej wizji dziejów homogenicznego społeczeństwa. Definitywna przemiana w nowoczesny naród i nowoczesne państwo, jak stwierdza Rudolf Chmel, jeszcze się nie dokonała, nadal pozostaje w sferze zadań do wykonania:

Jeszcze nie czujemy się w pełni Europejczykami, ale już wiemy, że nie ma odwrotu. Jesteśmy gdzieś w pół drogi, w okresie przejściowym. [...] Po plebejskim kolektywizmie musimy się dopracować nowoczesnego indywidualizmu, przejść od społeczeństwa zamkniętego lub półzamkniętego do jego wariantu otwartego, w którym ludzie mogą swobodnie okazywać swoje twórcze podejście - także wobec ojczyzny lub tożsamości narodowej33.

Proces budowania pluralistycznego modelu kultury dialogu, kształtowanie nowej, uznającej idee tolerancji oraz społeczeństwa otwartego świadomości i wrażliwości społecznej nadal na Słowacji trwa. Pewien niepokój wzbudzać może widoczne w ostatnich latach ożywienie ruchów antyliberalnych, obecność w debacie publicznej nacjonalistycznej retoryki, niemniej kierunek, jaki reprezentuje dominujący nurt, wydaje się opierać przede wszystkim na respektowaniu zasad państwa demokratycznego.

${ }^{33}$ R. Chmel, Zamknięta Słowacja..., s. 91. 